\title{
Critical Review: Antti Aikio and Mattias Åhrén (2014). A Reply to Calls for an Extension of the Definition of Sámi in Finland. Arctic Review on Law and Politics, Vol., No 1: 123-143
}

\author{
Ari Martin Laakso \\ M.Soc.Sci., Chair of the Finnish Association of Forest, Fisher and Mountain Sámi, \\ Vuontisjärvi, Finland
}

The question of who can be designated as Sámi is a contentious issue in Finland. The debate first escalated after the Act on the Sámi Parliament was approved in 1995. ${ }^{1}$ This Act identifies the Sámi people as the indigenous people of Finland. Several families who live inside the traditional Sámi home region, who are the descendants of the region's indigenous people, and who self-identify as belonging to the Sámi indigenous group, have applied for official status, but their applications have been rejected. Since then, members of this non-status Sámi group have struggled to achieve official recognition as Sámi, as members of an indigenous people of the region. The Sámi ethnopolitical elite strongly contested and continue to contest the claims of this group, as a result of which the debate continues.

The article by Antti Aikio and Mattias Åhrén must be viewed as a continuation of this Sámi ethnopolitical elite discourse, especially as the article has been used by Aikio to defend the rejection of applications provided by individuals belonging to this group, to be officially accepted as Sámi in Finland. Antti Aikio served as secretary for the Sámi Parliament election committee that decided during the 2015 Sámi Parliament elections who would be accepted as Sámi and who would not. ${ }^{2}$ Aikio is the son of the former President of the Finnish Sámi Parliament, Pekka Aikio, who also served as the chairman of the same election committee.

The Aikio and Åhrén article is a response to the publications of Tanja and Juha Joona. Their underlying assumption is that Joona and Joona want to extend the definition of who can be accepted as Sámi, especially by highlighting selfidentification by the individual. According to Tanja Joona, it is important to establish

^Correspondence to: Ari Martin Laakso, Proksintie 6, 99410 Vuontisjärvi, Finland. Email: arimartinlaakso@gmail.com 


\section{A. M. Laakso}

a more realistic definition of who is Sámi and who holds the rights to the land, to enable the ratification of ILO-Convention No.169. Aikio and Åhrén argue strongly against this view, and attempt to establish legal parameters that support their own position. Their main argument is that the Sámi who are currently recognized have the right to choose who is Sámi, and who is not, through the notion of group acceptance, and that ILO Convention No. 169 should be ratified regardless of who holds the rights to the land.

Evidence to support the line of argument in the Aikio and Åhrén article is scarce. Their argument is based on reviewing and commenting on Tanja Joona's publications, especially her doctoral dissertation. ${ }^{3}$ Their main concern with Joona's dissertation is that she argues that ILO 169 applies to individual indigenous persons who are of "Sámi origin" and who practice indigenous subsistence livelihoods. According to their counter argument: "It is irrelevant for the purposes of ILO 169 that an individual pursues subsistence livelihoods common to an indigenous (or tribal) people, if it cannot first be established that that person actually belongs to the group qualifying as indigenous (or tribal) pursuant to Article 1 of the Convention." With this statement, Aikio and Åhrén highlight a key factor in the debate over who is Sámi. One can only qualify as indigenous after the group has approved you as a member. Thus, an indigenous person who self-identifies as indigenous is not considered indigenous until the secretary of the election committee (Antti Aikio) accepts said indigenous person as Sámi and presents their case for approval to the Sámi Parliament election committee.

The arguments presented by Aikio and Åhrén contain several logical fallacies. Firstly, the indigenous rights highlighted by ILO 169 are based on the collective group rights of the indigenous people of a region. In the Sámi home region, these rights are also interpreted as being based on the individual rights of the indigenous people. ${ }^{4}$ Therefore, to argue that the indigenous people of the region have no say in establishing who is the rightful owner of these rights is illogical. Based on Korpijaakko-Labba's research regarding Sámi land rights, as well as available Lapp tax records, the current indigenous rights owners can easily be identified.

Secondly, the authors oversimplify and use false comparisons in their argument against Joona's assertion that ILO 169 Article 14 states the beneficiaries of the Convention. By taking subjects out of context, the authors create their own argumentation, such as on page 130: "It follows that, if an individual engages in a subsistence activity common to a particular indigenous people, one is a member of that indigenous people." Another descriptive example appears on page 131, where the authors offer reification to prove their argument: "To illustrate the problem with Tanja Joona's line of argument, to mention just one example, a comparison can be made with the right to education. ILO 169 Article 27 proclaims that indigenous (and tribal) children have the right to education. Since all children in Finland have the right to attend school, they should all qualify as Sámi children, if one accepts Tanja Joona's line of argument with regard to Article 14." Through this false comparison, they fall into the fallacy of using this abstraction to support their line of argument. An equally false comparison would be the argument that as all Sámi breath air and since all humans breath air, all humans are Sámi. 
Thirdly, Aikio and Åhrén defend their view by describing Joona's arguments as circular. On page 139, they write: "To use the criterion being of 'Sámi origin' to identify which individuals are Sámi makes little sense. It amounts to a circular argument. The purpose of any Sámi definition is precisely to identify which individuals are of 'Sámi origin'. Being of Sámi origin, cannot - per definition - be a criterion for identifying who is of Sámi origin." Here, the authors reformulate their key question - Who is Sámi?, to - Who is of Sámi origin? - in order to produce a counter argument using circular reasoning, and to criticize Tanja Joona's assertion that the criterion of being of "Sámi origin" should be employed in the Sámi designation in Finland.

The authors use the same argument of circular reasoning in relation to Joona's assertion that "Sámi livelihoods" should also be used as a criterion for the Sámi designation. They write: "Naturally, only Sámi individuals can know what are Sámi ways of life and livelihoods. Sámi livelihoods are - per definition - those identified as Sámi by those that are Sámi, at any given time." They continue: "Before it has been determined that a person is indeed Sámi, one cannot say that that person is engaged in Sámi livelihoods." As is evident from these excerpts, the authors are creating deliberate confusion between correlation and causation in relation to both Sámi origin and Sámi livelihoods as criteria for Sámi identification in Finland.

The practice of indigenous livelihoods is an underlying theme in the article. On page 138, indigenous subsistence livelihoods are deliberated on in connection with the definition of "Lapp." Aikio and Åhrén argue that it is "erroneous to equate 'Lapp' and 'Sámi'." According to their view, the term "Lapp" does not refer to ethnicity or culture but was created for fiscal purposes to divide people engaged in agriculture and people engaged in Sámi livelihoods. To support their argument, they refer to an article by Pekka Sammallahti. ${ }^{5}$ However, Sammallahti's article does not refer to any scientific research or firsthand material regarding the fiscal term "Lapp"; similarly, none of his previous publications make any such reference. ${ }^{6}$

The term "Lapp" has been used, among other scholars, by Olaus Magnus, ${ }^{7}$ Johannes Schefferus, ${ }^{8}$ Carl Linnæus, ${ }^{9}$ Lars Levi Læstadius ${ }^{10}$ and ethnographer Ernst Manker ${ }^{11}$ to describe the culture and livelihoods of Lapps. Together, their accounts cover more than a 400-year period. None of them refer to the term "Lapp" as originating for fiscal purposes. Therefore, Aikio's and Åhrén's argument that the term "Lapp" is only a fiscal denomination without any connection to ethnicity or culture must be critically questioned, especially as they fail to provide any scientific references to substantiate and validate their argument. Aikio's and Åhren's argument closely resembles the classic example of the fallacy of presentism described by historian David Hackett Fischer. ${ }^{12}$ Through denying the established meaning of the term "Lapp," the authors employ a rhetorical tactic that gives the appearance of a scientific debate. When scrutinized more closely, their arguments cannot be empirically substantiated, and are at odds with both scientific consensus and first hand evidence. As such, their arguments are only illogical assertions.

In their article, Aikio and Åhrén continue to provide exaggerated and unsubstantiated claims that must be viewed as a deliberate attempt to use the Arctic Review 


\section{A. M. Laakso}

on Law and Politics as a verification tool for ethnopolitical statements. The following statement on page 137 is problematic. "As to the suggestion that pursuit of reindeer herding, hunting and fishing should be employed as objective criteria in the Sámi definition in Finland, it is self-evident that this argument cannot be substantiated. That is so, since it is a fact that Finnish persons also engage in such activities. Any objective definition of 'Sámi individuals' must obviously be based on elements that distinguish a Sámi from a Finnish person. A Sámi definition cannot employ objective criteria that are common to the Sámi and Finnish peoples. That would - per definition - not be a definition of Sámi individuals."13

What makes this passage problematic is that Antti Aikio, in his role as secretary of the Sámi Parliament's election committee, has used this same argument to refuse to enlist indigenous people to the election roll and to be officially accepted as members of the indigenous people of Finland. ${ }^{14}$ In his argument for refusal, he applies the term "culture loan" to those whom he wishes to refuse. He argues that, even if their ancestors were designated as "Lapps" or "Flyttlapps" (nomadic Lapps) in the tax records, they were not ethnic Lapps, and their culture was not their own, but a cultural loan from the Sámi. Using the argument quoted above in combination with the term "culture loan" to support the rejection of an indigenous person's application to acquire official status as Sámi, stresses the need to assess the validity and reliability of this argument, which the authors fail to do. That such rejections help maintain the position of the present Sámi ethnopolitical elite in Finland is a concern that must be raised.

Aikio and Åhrén use the Kitok vs. Sweden case as an important precedent in their argument for group acceptance or membership governance as the core argument in defining who is Sámi and who is not in Finland. Contrary to their analysis and the analysis of other scholars, ${ }^{15}$ the Kitok vs. Sweden case does not support their argument that group acceptance should determine the indigenous identity of individuals. Even though Ivan Kitok was denied membership to the Sörkaitum Lapp village through the Swedish Reindeer Herding Act, he did not lose his Sámi status or identity. That he was denied access to the Sámi village was not due to his identity, as he was considered Sámi by origin. The Kitok vs. Sweden case must be viewed in relation to the division of rights inside the Sámi village and how this division affects the subsistence and livelihoods of its current members. As such, group acceptance can be seen as foregoing individual self-determination.

Aikio and Åhrén's article clearly supports the narrow view of the Finnish Sámi ethnopolitical elite regarding who has the right to official status as indigenous in Finland. Their biased article promotes the view that the Sámi ethnopolitical elite alone should determine who should be considered Sámi. Based on the arguments presented here, those people that the Sámi ethnopolitical elite do not accept as Sámi are categorically denied their history, culture and ethnicity through the unsubstantiated arguments that they have never been ethnic Lapps and that their culture and livelihoods are a cultural loan from the Sámi.

As shown, Aikio and Åhrén use the strategy of oversimplification to substantiate their arguments. By omitting relevant information, such as the complexity of the 
cultural, historical and genealogical identity of the indigenous people of the region, the authors try to argue that indigenous subsistence livelihoods and tax and church records cannot be used as criteria for Sámi identification. They even go so far as to rewrite the history of Lapps as a non-ethnic group without its own culture. Aikio and Åhrén thereby fall into the fallacy of presentism by creating their own subjective and non-scientific arguments and conclusions based on questionable references lacking reliability and validity.

The most disturbing outcome of Aikio's and Åhrén's article is the continued use of the Arctic Review on Law and Politics as a tool for verifying political arguments used by one of the authors to discriminate against Sámi individuals in Finland in the context of the Sámi parliament elections. As such, it is crucial that articles be written according to academic standards and based on scientific references. Seen in retrospect, the decision of the journal to approve this article for publication is disturbing from an academic and, more importantly, from a human rights perspective.

\section{NOTES}

1. Act on the Sámi Parliament (974/95).

2. Antti Aikio wrote a 17-page document called General Arguments for Rejection, arguing for the decision to reject 317 people from enlisting in the Sami Parliament election roll. This document was sent to each rejected applicant, of whom I was one. As secretary of the election committee of the Finnish Sami Parliament, Aikio bases his arguments for rejection on 6 scientific references, of which one is the article now under review. After reading through these few references, I became seriously concerned with the scientific quality and the political implication of Aikio's and Åhren's article. For this reason, I am writing a critical review of their article.

3. Tanja Joona, "The ILO Convention No. 169 in a Nordic Context with Comparative Analysis: An Interdisciplinary Approach” (PhD diss., Rovaniemi: Juridica Lapponica 37, 2012).

4. Kaisa Korpijaakko-Labba, "Saamelaisten oikeusasemasta Ruotsi-Suomessa" [Legal rights of the Sámi in Finland and Sweden during the period of Swedish rule] (PhD diss., Helsinki: Lakimiesliiton kustannus, 1989), 584; Juha Joona, "Kuka kuuluu alkuperäiskansaan Historian vastauksia tämän päivän kysymyksiin," [Who belongs to the indigenous people History's answer to current questions] Lakimieslehti 4 (2013), 754-755; and Sven Heurgren, Samerna - ett urprungsfolk i Sverige. Frågan om Sveriges anslutning till ILO: S kovention nr 169 [Sámi - an indigenous people in Sweden. The question of Sweden's ratification of the ILO Convention 169] (Stockholm: SOU 1999), 25, 147-148.

5. Pekka Sammallahti, Saamelaismääritelmästä, AGON 1-2 (2013): 28-29.

6. Sami Parliament's statement of the draft of the new Act on the Sami Parliament. The statement is a direct copy of Sammallahti's article in AGON (1-2) 2013.

7. Olaus Magnus, A Description of the Northern Peoples (Rome: 1555), trans. Peter Fisher and Humphrey Higgens, ed. Peter Foote (London: The Hakluyt Society, 1996): 197-224.

8. Johannes Schefferus, The History of Lapland: wherein are shewed the original manners, habits, marriages, conjurations, \&c. of that people (Oxford:1674), Reprint (Stockholm: Rediviva Publishing House, 1971) http://urn.fi/URN:NBN:fi-fd2010-00003224 (accessedMarch 4 2016).

9. Carl Linnæus, Lachesis Lapponica: A Tour in Lapland (London: White and Cochrane, 1811). 


\section{A. M. Laakso}

10. Lars Levi Læstadius, Fragments of Lappish Mythology (Beaverton, OR: Aspasia Books, 2002).

11. Ernst Manker, The nomadism of the Swedish mountain Lapps (Stockholm: Hugo Gebers Förlag, 1953).

12. David Hackett Fischer, Historian's Fallacies: Toward a logic of historical thought (New York: Harper \& Row, 1970).

13. Employing objective criteria that are common to both people may not be definitive in defining the Sámi, but it may nevertheless be among the criteria that defines the Sámi in combination with other criteria.

14. The general arguments for rejection can be found as an attachment to the Finnish Highest Supreme Court decision: KHO 30.9.2015 t. 2717.

15. Kamrul Hossain, "Protection of Sami Reindeer Herding in the Context of Finnish Mining Legislation: A Reflection from Article 27 of the ICCPR," in Reforming mining law in a changing world with special reference to Finland, ed. Timo Koivurova and Adam Stepien (Rovaniemi: Juridica Lapponica 34, 2008), 91-105. 